\title{
The effects of processing on the nutritive value of vegetable- protein concentrates
}

\author{
By A. A. Woodham, Roweit Research Institute, Bucksburn, Aberdeen AB2 $9 S B$
}

Vegetable-protein concentrates may be divided, on the one hand, into conventional products such as legumes and oilseeds which may be eaten directly or after the extraction of commercially valuable oil and, on the other, non-conventional products such as the concentrates produced from green leaves by pulping and protein precipitation, and edible products prepared from protein isolates. Such isolated proteins may be further treated in order to produce textured foods simulating meat products. Conventional concentrates may be eaten by both man and animals, whereas the non-conventional products, although they may be given experimentally, to animals, are designed for human feeding and by virtue of their cost of production could not compete with natural animal feeds. Conventional protein foods may be subjected to further processing, over and above that needed for oil extraction, in order to improve palatability or in order to modify them so that they may be better utilized during digestion.

Factors operating during the production of both conventional and nonconventional protein sources which may be expected to influence nutritive value are light, contact with chemicals, and above all, heat. Heat is involved in drying of the raw material, in oil extraction, and may be used to improve the palatability of the product as well as in some methods of conferring a protective mechanism. Damage may be done to vitamins as well as to proteins.

It is proposed here to deal briefly with the more important vegetable-protein concentrates used in animal feeding and then at somewhat greater length with the cruciferous oilseeds. The latter have attracted considerable attention in recent years because of their increasing economic importance and because of the possibility that they might contribute significantly to ameliorating the world protein shortage. The importance of protein quality in ruminant diets is now recognized and the recent work on protected proteins will be discussed. Finally, the protein isolates and textured proteins which are designed for human feeding will be briefly mentioned from the point of view of processing.

\section{Soya-bean meal}

Because of its high content of lysine compared with many other plant protein sources, soya bean continues to be of supreme importance as a constitutent of nonruminant feeds, and recent high prices for fish meal have accentuated this importance. A number of factors have been said to be responsible for the growth depression 
associated with raw soya beans but the mechanism is elusive, though a survey of papers published in the last decade suggests that less effort than previously is now being devoted to the problem. This is doubtless because over the years, and presumably largely by a process of trial and error, the processing conditions necessary for the production of a consistently satisfactory meal from soya beans has been achieved. This is certainly so in the main producing countries, the USA and Canada. The earlier emphasis on maximum yield and quality of oil at the expense of the residual meal has been modified as a result of the need to produce a highquality meal for animal feeding. The work on soya-bean processing has directly benefited other oilseeds, where problems of trypsin-inhibitor inactivation and lysine availability are also important. Precise details of processing conditions are difficult to obtain and in any event vary somewhat from mill to mill. Variations are most likely to occur with regard to time and temperature of cooking after the initial crushing of the seed.

\section{Groundnut meal}

Conditions for groundnut processing were summarized by Woodham $\&$ Dawson (1968). Liener (1958) suggested that high nitrogen solubility was a desirable characteristic in groundnut meals but a more recent comparison of products obtained commercially with groundnut flours prepared under controlled conditions of heating led to the conclusion that, although the levels of moist heat normally encountered may affect the solubility characteristics of the protein, they are likely to have little effect upon the nutritive value of the product (Woodham \& Dawson, 1968). Whereas for soya bean, evidence has been obtained that the higher temperatures involved in screw-pressing, as compared with solvent extraction, may adversely affect the quality, no difference was found for groundnut meals (Duckworth, Woodham \& McDonald, i961). On the other hand, Wessels (1967) has claimed that solvent extraction and steam-stripping of groundnuts may destroy or render unavailable some of the methionine.

\section{Cottonseed meal}

As with other oilseed meals, controlled heating is desirable in the production of feeding-meal but the main problem concerns the removal or inactivation of gossypol. Solvent extraction with an acetone-hexane-water $(52: 44: 3$, by vol.) mixture (Mann, Carter, Frampton, Watts \& Johnson, I962) or with acetone containing $250-300 \mathrm{ml}$ water $/ 1$ (Pons $\&$ Eaves, 1967 ) have been found satisfactory. Avoidance of the problem by the development of non-toxic glandless cottonseed may not be a viable alternative, at least in the near future, because of low crop yields and disease problems, but solvent-extracted meal from conventional seed has been found suitable for laying birds as judged by the proportions of discoloured yolks and whites (Proctor, O'Neill, Reilich, Levi \& Pons, 1968).

\section{Cruciferous oilseeds}

Included in this family are three very important oilseeds-rape, mustard and 
crambe. All are unsuitable for feeding directly because they contain glucosinolates which break down through chemical or enzyme action to yield toxic products. Consequently, in addition to removal of oil, a main aim of any processing procedure must be the removal of these constituents from the seed or inactivation of the breakdown products. The characteristics of the three oilseeds are somewhat different, and it will be convenient to examine them separately.

Rapeseed. Conventional screw-press, pre-press solvent extraction, and direct solvent extraction methods have all been used for oil removal and, as with other classes of oilseed, there is the danger of influencing adversely the lysine content if conditions are not carefully controlled (Clandinin \& Tajcnar, 196r). Even when expeller processing was sufficiently mild to leave behind $6 \%$ of oil, damage occurred. A mild pre-press solvent extraction resulted in little loss of lysine, however, and high lysine values have also been found in solvent-extracted meals (Youngs, 1965).

Enzymic hydrolysis of rapeseed thioglucosides give rise to oxazolidinethione as well as volatile isothiocyanates, the latter only being removable by steam-stripping. It has been claimed that, if the meal is cooked in the absence of moisture, breakdown of the thioglucosides does not occur and their presence does not affect the nutritional qualities of the residual meal (Reynolds \& Youngs, 1964). Early attempts at detoxification of rapeseed by autoclaving, extraction with hot water or ethanol or dry heating, met with very variable degrees of success (Bell \& Baker, 1957; Gray, Hill \& Branion, 1958; Belzile, Bell \& Wetter, I963; Holmes \& Roberts, I963; Nakaya \& Nakamura, I963). It appears that a product free of myrosinase and containing unhydrolysed thioglucosides is satisfactory for feeding. A wet-heat treatment facilitates removal of the hulls - difficult when moisture is excluded-and a process was developed by Eapen, Tape \& Sims (I968) which inactivates the myrosinase and gives a better-quality meal. Attempts to decompose the glucosinolates with iron, copper, or nickel salts (Sallans, Phillip, Spencer \& Youngs, I967) were unsatisfactory as the toxic and non-volatile I-cyano-2-hydroxy-3-butene was produced. Eapen, Tape \& Sims (1969) have subsequently produced a light-coloured bland defatted flour, low in glucosinolates. The enzyme is first inactivated by boiling for $2 \mathrm{~min}$ in water, and the seed wet-ground at ambient temperature $\left(20^{\circ}\right)$, extracted several times with water, dried, flaked and extracted with hexane. It was found that the low-temperature aqueous extraction gave as good a removal of toxic material as did higher temperatures, with smaller losses of solids (Sims, I971). Another recently published process involves double aqueous extraction, again at room temperature, first for 8- $\mathrm{I} 4 \mathrm{~h}$ and then again for $\mathrm{I}-3 \mathrm{~h}$ (Ballester, Rodrigo, Nakouzi, Chichester, Yanez \& Monckeburg, 1970). A novel approach involving the destruction of glucosinolates in rapeseed press-cake by the action of a fungus, Geotrichum candidum, has also been reported (Staron, 1970). Pakistan workers have obtained a glucosinolate-free protein isolated by extracting defatted rapeseed meal with aq. $\mathrm{NaOH}$ and precipitating the protein at $\mathrm{pH} 4^{\circ}$ (Shaikh, Arshad, Haque \& Ali, I968).

Mustard seed. As mustard seed contains only one glucosinolate which yields on hydrolysis volatile products only, the problem of detoxifying it is relatively simple. Moistening the seed to give a total water content of $300 \mathrm{ml} / 1$ is followed by a reaction 
period of $\mathrm{I} h$ at $53^{\circ}$, after which the volatile mustard oil is distilled off using sparge steam. Air-drying of the product and extraction with hexane yielded a product containing a very low concentration of isothiocyanate (Mustakas, Griffin, Gastrock, D'Aquin, Keating $\&$ Patton, ${ }_{1963}$ ). More recently, a milder process involving aqueous hydrolysis of defatted mustard meal at $\mathrm{pH} 8.2$ and room temperature for 4 to $5 \mathrm{~h}$ has been reported (Urs \& Parpia, 1969). Liberated mustard oil was removed by distillation, the slurry cooled and $\mathrm{pH}$ adjusted to $5^{\circ} \mathrm{O}$. A bitter constituent still remaining was removed by a single water wash.

Crambe seed. The importance of crambe oil as a source of erucic acid has ensured the ready availability of crambe meal, and various ways of inactivating the toxic glucosinolates have been examined. A procedure based on acetone extraction of wetted meal was developed (Van Etten, Daxenbichler, Peters \& Wolff, r 965 ), and this led to a procedure involving the autolysis of dehulled, defatted crambe seed followed by extraction with aqueous acetone which yielded a product allowing $88 \%$ of the rat growth permitted by control animals over a 13 -week test period (Tookey, Van Etten, Peters \& Wolff, 1965). Later, meals thus prepared but without heat treatment, were found to have protein efficiency ratios (PER) of 2.55 to 2.75 relative to a casein value of 2.50 (Van Etten, Gagne, Robbins, Booth, Daxenbichler $\&$ Wolff, 1969). Ammoniation also improved the nutritive value of the seed for pigs and poultry (Kirk, Mustakas \& Griffin, I966) but the product was unpalatable for calves in long-term feeding trials. Better palatability for cattle and poultry was found for a product obtained by treatment of the seed with soda ash at a level of $14 \mathrm{~g} / \mathrm{kg}$ based on whole-seed weight (Mustakas, Kirk \& Griffin, I968). It has been discovered recently that salts of iron and copper will decompose the thioglucoside, epi-progoitrin without reducing the lysine content, and rats given $\mathrm{FeSO}_{4}$-treated crambe-seed meal as $300 \mathrm{~g} / \mathrm{kg}$ of the total diet gained $70 \%$ of the weight gained by controls. There was a $50 \%$ enlargement of the thyroid, however, although similar meal without $\mathrm{FeSO}_{4}$ caused $100 \%$ mortality in 2 weeks (Kirk, Mustakas, Griffin \& Booth, 197I). Blanching of the seeds followed by leaching of the glucosinolates with hot water appears to be a possible process (Van Etten et al. 1969), but detoxified crambe-seed meal has not yet been used in human feeding.

\section{Protein protection for ruminants}

One of the most interesting processing developments of recent years concerns the attempts to improve the utilization of protein by the ruminant animal by limiting the extent of degradation in the rumen. In this instance the processing is not merely an inevitable adjunct associated with facilitating the production of a prime product such as oil, nor is it applied in order to increase the palatability of the food. The object is to preserve the protein intact during its passage through the fore-stomach, thereby avoiding the wasteful production of ammonia. Only a certain amount of ammonia can be utilized by the rumen micro-organisms. Excessive production is excreted. Black ( $197 \mathrm{r}$ ) showed that fermentation of dietary protein in the rumen of a $20 \mathrm{~kg}$ lamb halved the quantity of protein available for utilization. 'This clearly indicates the advantages of limiting the extent of attack in the rumen. 
Reduction of protein degradation in the rumen might be achieved in several ways. Proteins which are naturally insoluble in rumen fluid, such as zein, will obviously resist attack (Ely, Little, Woolfolk \& Mitchell, 1967) but such proteins are likely also to be poorly digested in the small intestine (Little \& Mitchell, 1967), so no advantage accrues. More effective is the use of techniques which speed the passage of the protein through the rumen, such as the provision of high levels of salt in the diet (Hemsley, 1967 ) or reduction of the dietary hay : concentrate ratio (McGilliard, 1972). The bypassing of the rumen by encouraging closure of the oesophageal groove (Ørskov \& Benzie, I969) is also possible, as is the encapsulation of amino acid supplements (Broderick, Kowalczyk \& Satter, 1970). However, the most promising approach seems to be the modification of protein in order to reduce its susceptibility to microbial attack. Mere heating of groundnut and soya-bean meals has been found to be effective (Tagari, Ascarelli \& Bondi, 1962; Chalmers, Jayasinge \& Marshall, 1964). The reduced proteolysis in the rumen was considered to be of greater importance than reduction in nutritive value in the lower gut due to essential amino acids being rendered unavailable.

Recently Ferguson, Hemsley \& Reis (1967) have found that treatment of casein with formaldehyde renders it resistant to microbial attack. Peter, Hatfield, Owens \& Garrigus (I97I) screened a number of aldehydes in order to see which were most effective for depressing protein degradation in soya-bean meal, and formaldehyde $(0 \cdot 6 \%)$, glyoxal $(\mathrm{r} \cdot 5 \%)$ and gluteraldehyde $(\mathrm{r} \cdot 5 \%)$ were found to be effective in vitro and in vivo for reducing protein solubility and ammonia production by rumen micro-organisms. The same authors carried out nitrogen-balance experiments with lambs and found that all the aldehyde-treated soya-bean meals significantly increased nitrogen retention and weight gain without affecting wool growth. Using a maize diet supplemented with aldehyde-treated soya bean for steers in 'feedlot' trials, however, produced little or no improvement. Formaldehyde treatment of groundnut meal, on the other hand, has been shown not only to reduce ammonia production in vitro but also to increase wool growth when given to sheep, nitrogen retention being unaffected and nitrogen digestibility being lowered (Hughes \& Williams, 1971). Miller (1972) found that formaldehyde treatment of groundnut meal did not affect digestibility in lambs; however, nitrogen flow to the abomasum was increased as was faecal nitrogen excretion. Approximately $70 \%$ of the extra nitrogen reaching the abomasum was absorbed.

Although it seems clear that aldehyde treatment of oilseed meals can be beneficial for the ruminant, not enough is yet known regarding the processing conditions which give the optimum result. For example, in the experiments of Hughes \& Williams ( $197 \mathrm{I})$ referred to above the groundnut meal was treated with $200 \mathrm{ml}$ $10 \%$ formaldehyde solution $/ \mathrm{kg}$ for $7 \mathrm{~d}$, whereas Miller (1972) gave an overnight treatment $\left(\mathrm{I}_{5} \cdot 5 \mathrm{~h}\right)$ with $500 \mathrm{ml} \mathbf{2 \cdot 4} \%$ formaldehyde solution $/ \mathrm{kg}$. More definitive experiments using meals prepared under controlled conditions are needed.

Very recently there have been reports of the protection of proteins by lipid encapsulation and, as it seems likely that such a process would have a less drastic 
effect on protein quality than the chemical treatments described above, this development would appear to be a promising one.

\section{Textured vegetable protein}

The most significant development in the use of vegetable proteins in human feeding in recent years has involved the preparation of fibres by extrusion of the protein with subsequent spinning to give a textured product simulating meat. Rat growth assays of the PER type have demonstrated that the nutritive value of such meat analogues is similar to that of toasted soya-bean flour (Wilding, 1969). Analogues made from spun fibres in combination with egg and other protein-binders yielded material having PER equal to $2 \cdot 2$ to $2 \cdot 4$ (Thulin \& Kuramoto, 1967). However, the products are still so new that many more nutritional evaluations are needed to indicate their true potential. It seems likely that vitamin supplementation will certainly be necessary to make good the processing damage, though it may well be that the nutritive value of the protein is not seriously affected.

\section{Leaf-protein concentrate}

During the last decade considerable work has been done on the processing and nutritional evaluation of protein concentrates from various species of leafy crops. Although the products have varied somewhat, there seems little doubt now that most leaves will yield a nutritionally satisfactory product, provided that the precipitated protein is thoroughly washed and that the temperature used for drying is not excessive. Grass and cereal leaves are suitable, and with all leaves toxic constituents do not accompany the isolated protein. Fairly extensive testing has been done on animals and human feeding trials are continuing (Pirie, 197r).

\section{REFERENCES}

Ballester, D., Rodrigo, R., Nakouzi, J., Chichester, C. O., Yanez, E. \& Monckeberg, F. (1970). F. Sci. Fd Agric, 21, 140.

Bell, J. M. \& Baker, E. (1957). Can. F. Anim. Sci. 37, 21.

Belzile, R., Bell, J. M. \& Wetter, L. R. (1963). Can. 7. Anim. Sci. 43, I69.

Black, J. L. (I971). Br. F. Nutr. 25, 3 I.

Broderick, G. A., Kowalczyk, T. \& Satter, L. D. (1970), F. Dairy Sci. 53, 1714.

Chalmers, M. I., Jayasinge, J. B. \& Marshall, S. B. M. (I964). F. agric. Sci., Camb. 63, 283.

Clandinin, D. R. \& Tajcnar, E. W. (I96r). Poult. Sci. 40, 29 r.

Duckworth, J., Woodham, A. A. \& McDonald, I. (196r). F. Sci. Fd Agric. 12, 407.

Eapen, K. E., Tape, N. W. \& Sims, R. P. A. (1968). F. Am. Oil Chem. Soc. 45, 194

Eapen, K. E., Tape, N. W. \& Sims, R. P. A. (I969). F. Am. Oil Chem. Soc. 46, 52.

Ely, D. G., Little, C. O., Woolfolk, P. G. \& Mitchell, G. E. (I967). F. Nutr. 9x, 3 I4.

Ferguson, K. A., Hemsley, J. A. \& Reis, P. J. (1967). Aust. F. Sci. 30, 215.

Gray, J. A., Hill, D. C. \& Branion, H. D. (1958). Poult. Sci. 37, 734.

Hemsley, J. A. (I967). Aust. F. exp. Biol. med. Sci. 45, 39.

Holmes, W. B. \& Roberts, R. A. ( (963). Poult. Sci. 42, 803 .

Hughes, J. G. \& Williams, G. L. (I97I). Anim. Prod. 13, 396.

Kirk, L. D., Mustakas, G. C. \& Griffin, E. L. (1966). F. Am. Oil Chem. Soc. 43, $55^{\circ}$.

Kirk, L. D., Mustakas, G. C., Griffin, E. L. \& Booth, A. N. (197I). F. Am. Oil Chem. Soc, 48, 845.

Liener, I. E. (1958). In Processed Plant Protein Foodstuffs p. 79 [A. M. Altschul, editor]. New York: Academic Press Inc.

Little, C. O. \& Mitchell, G. E. (1967). F. Anim. Sci. 26, 4 Ir.

Mann, G. E., Carter, F. L., Frampton, V. L., Watts, A. B. \& Johnson, C. (1962). J. Am. Oil Chem Soc. 39, 86. 
McGilliard, A. D. (1972). \%. Am. Oil Chem. Soc. 49, 57.

Miller, E. L. (1972). Proc. Nutr. Soc. 31, 27A.

Mustakas, G. C., Griffin, E. L., Gastrock, E. A., D'Aquin, E. L., Keating, E. J. \& Patton, E. L. (1963). Biotech. Bioeng. 5, 27.

Mustakas, G. C., Kirk, L. D. \& Griffin, E. L. (xg68). F. Am. Oil Chem. Soc. 45, 53.

Nakaya, T. \& Nakamura, R. (1963). Fap. F. zootech. Sci. 34, 253.

Ørskov, E. R. \& Benzie, D. (I969). Proc. Nutr. Soc. 28, 3०A.

Peter, A. P., Hatfield, E. E., Owens, F. N. \& Garrigus, U. S. (1971). 7. Nutr, ror, 605.

Pirie, N. W. (editor) (1971). Leaf Protein : IBP Handbook no. 20. Oxford and Edinburgh: Blackwell.

Pons, W. A. \& Eaves, P. H. (r 667 ). 7. Am. Oil Chem. Soc. 44, 46o.

Proctor, J., O’Neill, H. J., Reilich, H. G., Levi, R. S. \& Pons, W. A. (1968). 7. Am. Oil Chem. Soc. 45, 393.

Reynolds, J. R. \& Youngs, C. G. (1964). F. Am. Oil Chem. Soc. 4x,63.

Sallans, H. R., Phillips, K. L., Spencer, J. F. T. \& Youngs, C. A. (1967). Natn. Res. Coun. Rev., Ottawua.

Shaikh, I. A., Arshad, M., Haque, M. Y. I. \& Ali, S. M. (r968). Pakist. F. scient. ind. Res. rx, 263.

Sims, R. P. A. (1971). F. Am. Oil Chem. Soc. 48, 733.

Staron, T. (1970). Proc. int. Conf. Sci. Tech. Marketing of Rapeseed and Products. St. Adele, Canada.

Tagari, H., Ascarelli, I. \& Bondi, A. (1962). Br. F. Nutr. 16, 237.

Thulin, W. W. \& Kuramoto, S. (I967). Fd Technol., Champaign 21, 64.

Tookey, H. L., Van Etten, C. H., Peters, J. E. \& Wolff, I. A. (1965). Cereal Chem. 42, 507.

Urs, M. K. \& Parpia, H. A. B. (1969). FAO/WHO Protein Advisory Group meeting Geneva. Doc. $2.35 / 1$.

Van Etten, C. H., Daxenbichler, M. E., Peters, J. E. \& Wolff, I. A. (1965). F. agric, Fd Chem. 13, 24.

Van Etten, C. H., Gagne, W. E., Robbins, D. J., Booth, A. N., Daxenbichler, M. E. \& Wolff, I. A. (1969). Cereal Chem. 46, I45.

Wessels, J. P. H. (1967). S. Afr. F. agric. Sci. ro, I13.

Wilding, M. D. (1969). F. agric. Fd Chem. 18, soog.

Woodham, A. A. \& Dawson, R. (1968). Br. F. Nutr. 22, 589 .

Youngs, C. G. (1965). In Rapeseed Meal for Livestock and Poultry p. 24 [J. P. Bowland, D. R. Clandinin and L, R. Wetter, editors]. Ottawa: Canadian Department of Agriculture. 